\title{
Transduced Tat-DJ-1 protein inhibits cytokines-induced pancreatic RINm5F cell death
}

\author{
Hyo Sang Jo", Hyeon Ji Yeo", Hyun Ju Cha, Sang Jin Kim, Su Bin Cho, Jung Hwan Park, Chi Hern Lee, Eun Ji Yeo, \\ Yeon Joo Choi, Won Sik Eum ${ }^{*} \mathcal{E}$ Soo Young Choi* \\ Department of Biomedical Science and Research Institute of Bioscience and Biotechnology, Hallym University, Chunchon 24252, Korea
}

\begin{abstract}
Loss of pancreatic $\beta$-cells by oxidative stress or cytokines is associated with diabetes mellitus (DM). DJ-1 is known to as a multifunctional protein, which plays an important role in cell survival. We prepared cell permeable wild type (WT) and mutant type (M26I) Tat-DJ-1 proteins to investigate the effects of DJ-1 against combined cytokines (IL-1 $\beta$, IFN- $\gamma$ and TNF- $\alpha$ )-induced RINm5F cell death. Both Tat-DJ-1 proteins were transduced into RINm5F cells. WT Tat-DJ-1 proteins significantly protected against cell death from cytokines by reducing intracellular toxicities. Also, WT Tat-DJ-1 proteins markedly regulated cytokines-induced pro- and anti-apoptosis proteins. However, M26I Tat-DJ-1 protein showed relatively low protective effects, as compared to WT Tat-DJ-1 protein. Our experiments demonstrated that WT Tat-DJ-1 protein protects against cytokine-induced RINm5F cell death by suppressing intracellular toxicities and regulating apoptosisrelated protein expression. Thus, WT Tat-DJ-1 protein could potentially serve as a therapeutic agent for DM and cytokine related diseases. [BMB Reports 2016; 49(5): 297-302]
\end{abstract}

\section{INTRODUCTION}

Diabetes mellitus (DM), a chronic metabolic disease, is associated with destruction of pancreatic $\beta$-cells or progressive loss of $\beta$-cell function in pancreas tissues. DM incidence is rapidly increasing and many people are diagnosed or affected worldwide (1-3). Both oxidative stress and inflammation are highly associated with DM and play important roles in the

*Corresponding authors. Soo Young Choi, Tel: +82-33-248-2112; Fax: +82-33-241-1463; E-mail: sychoi@hallym.ac.kr, Won Sik Eum, Tel: +82-33-248-2112; Fax: +82-33-241-1463; E-mail: wseum@ hallym.ac.kr

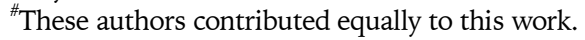

http://dx.doi.org/10.5483/BMBRep.2016.49.5.058

Received 16 March 2016, Revised 18 March 2016, Accepted 18 March 2016

Keywords: Cytokines, Protein therapy, Tat-DJ-1, Toxicity, Wild type and mutants development of DM (4). In addition, several studies have demonstrated that pro-inflammatory cytokines in type 2 DM contribute to $\beta$-cell dysfunction and death by insulin resistance (5-7). Therefore, the regulation of oxidative- or cytokine-induced stress is important in protecting the pancreatic $\beta$-cell damage.

DJ-1 is a multifunctional protein that exists in most human tissues including the pancreas (8). Many studies have demonstrated that DJ-1 plays an important role as an antioxidant protein. In a Parkinson's disease (PD) animal model, overexpressed DJ-1 demonstrated a protective function against neuronal cell death induced by oxidative stress, whereas knockdown DJ-1 protein increased neuronal oxidative stress induced cell death $(9,10)$. Also, overexpression of DJ-1 protein protects against oxidative stress-induced H9C2 cell damage (11) and transduced Tat-DJ-1 protein protects against ischemic damage (12). In contrast, many missense DJ-1 mutants have been identified including $\mathrm{M} 26 \mathrm{l}$, which are known to have lost DJ-1 function. However, the function of DJ-1 mutant is still fully unknown (13). Although the antioxidant function of DJ-1 is well known in neuronal disease, the function of $D J-1$ in pancreatic $\beta$-cells remains unclear.

Protein transduction domains (PTDs) or cell penetrating peptides (CPPs) are small peptides with the ability of facilitate the delivery of therapeutic target proteins into cells across cellular membranes (14). Many studies have demonstrated that PTD fusion proteins transduce into cells/tissues and protect against a variety of stress induced cell damage (15-22). In a previous study, Kim et al. demonstrated that Tat-DJ-1 protein transduced into neuronal cells protected against ischemic damage (12). Here, we investigated the effect of Tat-DJ-1 protein in cytokine-induced pancreatic $\beta$-cell death and showed that transduced WT Tat-DJ-1 protein markedly protected against cytokine-induced pancreatic $\beta$-cell death.

\section{RESULTS AND DISCUSSION}

Purified Tat-DJ-1 protein transduced into RINm5F cells DJ-1 expression is known to play a crucial role in protecting against cell death by a variety of stimuli (23). However, the effect of wild type DJ-1 or M26I mutant DJ-1 proteins on pancreatic $\beta$-cell death is poorly understood. To examine the effect of DJ-1 proteins against cytokine-induced cell death, cell

ISSN: 1976-670X (electronic edition)

Copyright (c) 2016 by the The Korean Society for Biochemistry and Molecular Biology

(c) This is an open-access article distributed under the terms of the Creative Commons Attribution Non-Commercial License (http://creativecommons.org/licenses/by-nc/4.0) which permits unrestricted non-commercial use, distribution, and reproduction in any medium, provided the original work is properly cited. 
permeable WT Tat-DJ-1 and M26I Tat-DJ-1 proteins were constructed and purified. Also, we constructed and purified control DJ-1 protein without a Tat peptide. Tat peptides are one of a variety of protein transduction domains (PTDs) that are widely used to transduce therapeutic molecules into cells (18). As shown in Figs. 1A-1C, we confirmed purified Tat-DJ-1 proteins by SDS-PAGE and Western blot analysis using an anti-histidine antibody. Next, we examined purified DJ-1 protein transduction into RINm5F cells. Immunofluorescence data demonstrated that purified Tat-DJ-1 proteins were markedly detected in the cytoplasm and nucleus of RINm5F cells (Fig. 1D). The results of these experiments demonstrated the successful transduction of purified Tat-DJ-1 protein into RINm5F cells.

The transduction efficiency of Tat-DJ-1 proteins into pancreatic RINm5F cells was determined by treating RINm5F cells with various Tat-DJ-1 proteins $(0.5-3 \mu \mathrm{M})$ for $1 \mathrm{~h}$ or with Tat-DJ-1 proteins $(3 \mu \mathrm{M})$ for various times (5-60 min). Then, transduction efficiency analysis was conducted by Western blotting. As shown in Fig. 2, Tat-DJ-1 proteins were transduced into RINm5F cells time- or dose-dependently. However, WT
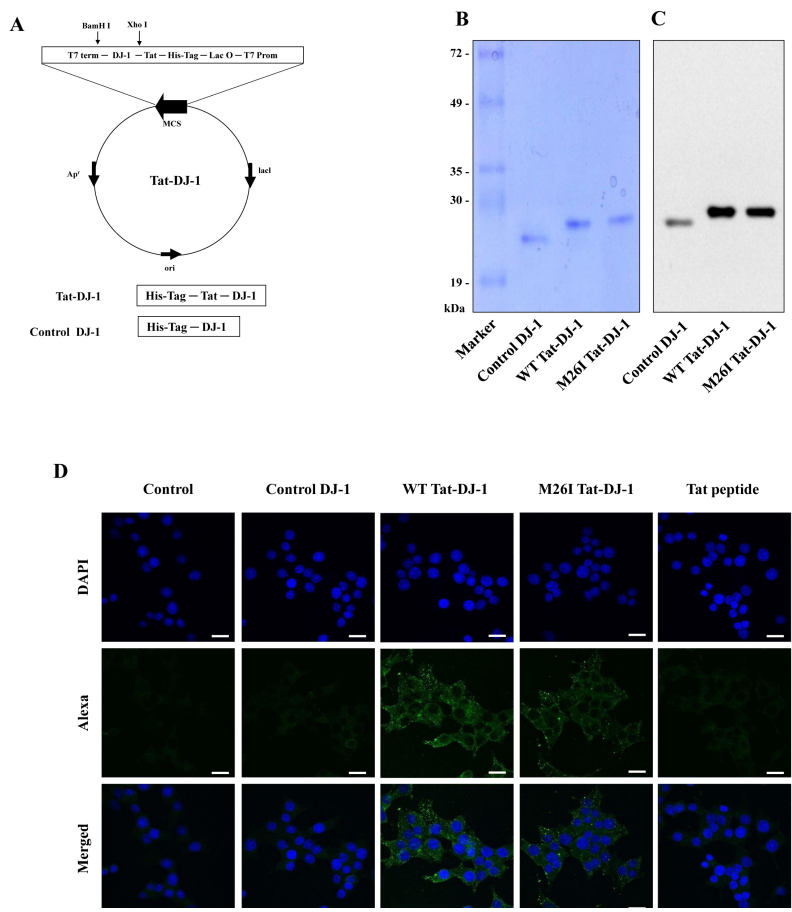

Fig. 1. Construction and purification of Tat-DJ-1 proteins. A schematic representation of the Tat-DJ-1 proteins (A). Purified Tat-DJ-1 proteins were analyzed by $12 \%$ SDS-PAGE (B) and subjected to Western blot analysis with an anti-rabbit polyhistidine antibody (C). Transduction of Tat-DJ-1 protein into RINm5F cells. Cells were treated with Tat-DJ-1 $(3 \mu \mathrm{M})$ proteins for $1 \mathrm{~h}$ and transduced Tat-DJ-1 proteins were observed by confocal microscopy (D). Scale bar $=20 \mu \mathrm{m}$.
Tat-DJ-1 proteins were more rapidly transduced into the cells as compared to M26I Tat-DJ-1 proteins; whereas, control DJ-1 protein did not transduce into cells. Also, we confirmed the intracellular stability of Tat-DJ-1 proteins in RINm5F cells. The quantity of WT Tat-DJ-1 proteins persisted in the cells for $24 \mathrm{~h}$, as compared to M26I Tat-DJ-1 proteins. Other studies have demonstrated lower and highly unstable mutant DJ-1 protein levels, as compared with WT DJ-1 protein $(24,25)$.

\section{Tat-DJ-1 protein inhibited cytokine-induced cellular cytotoxicity}

Pro-inflammatory cytokines such as IL-6, IL-1 $\beta$, TNF- $\alpha$ and oxidative stress are major risk factors to induce pancreatic $\beta$-cell death, since antioxidant protein expression levels in pancreas tissues are lower than those found in other tissues (5, $7,26)$. Thus, we determined whether Tat-DJ-1 protein protects against cytokine-induced RINm5F cell death using a MTT assay. As shown in Fig. 3A, WT Tat-DJ-1 protein markedly increased cell survival up to $67 \%$ against cytokine-induced cell death while M26I Tat-DJ-1 protein slightly increased cell survival $(51 \%)$ and control DJ-1 protein did not affect cell survival compared to the survival $(48 \%)$ of cytokine alone treated cell. In addition, we examined the effects of Tat-DJ-1 protein on cytokine-induced ROS production and DNA fragmentation. RINm5F cells were pretreated with Tat-DJ-1 protein for $1 \mathrm{~h}$ and exposed to cytokines. Subsequently, intracellular ROS levels were determined. Intracellular ROS levels were significantly increased by cytokines, while WT Tat-DJ-1 protein markedly reduced ROS levels compared to the levels of cytokine treated cells. However, M26I Tat-DJ-1 and control DJ-1 protein did not affect ROS production (Fig. 3B). We also determined DNA fragmentation levels. As shown in Fig. 3C, cytokines markedly increased the green fluorescence stained cells, as compared with the control cells. WT Tat-DJ-1 treated cells drastically reduced green fluorescence stained cells; whereas, M26I Tat-DJ-1 proteins treated cells showed slightly reduced staining and control DJ-1 protein did not affect DNA fragmentation in cytokine treated RINm5F cells. Previous studies have shown the protective effects of the overexpression of antioxidant proteins against pancreatic $\beta$-cell death caused by cytokine- or ROS-induced cellular toxicity $(27,28)$. In agreement with other studies, we have demonstrated that WT Tat-DJ-1 protein significantly protected against cytokine-induced RINm5F cell death. Our results demonstrated that WT Tat-DJ-1 proteins act as an antioxidant against cytokine-induced RINm5F cell death.

\section{Tat-DJ-1 protein inhibits cytokine-induced signaling in RINm5F cells}

Several studies have demonstrated that excesses of cytokines and oxidative stress lead to apoptosis via mitochondria dysfunction and intrinsic apoptosis pathways. The intrinsic apoptosis pathway is triggered by cytochrome $c$ release from mitochondria. Released cytochrome $c$ enhances the activation 
A
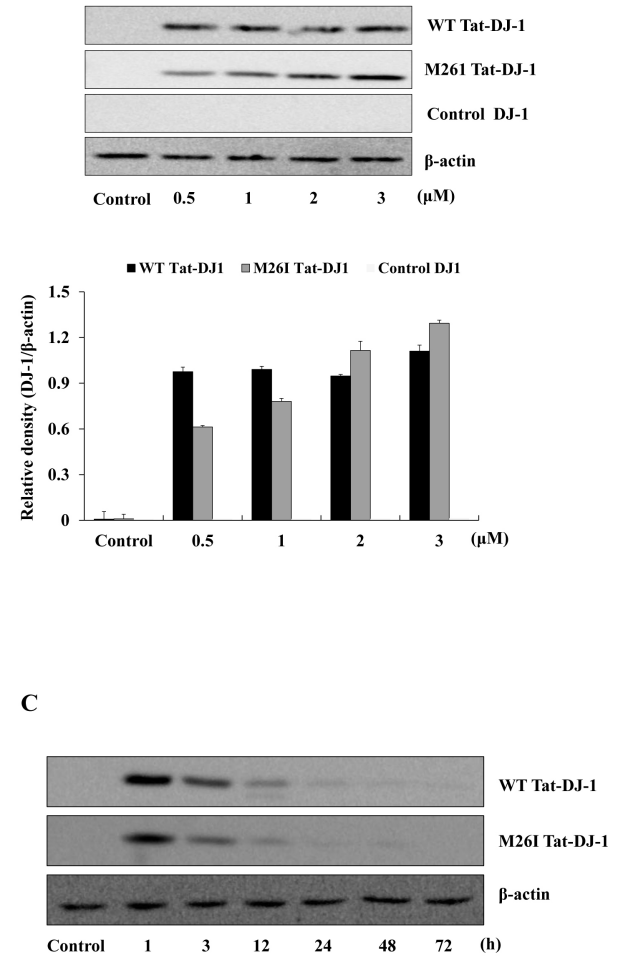

A

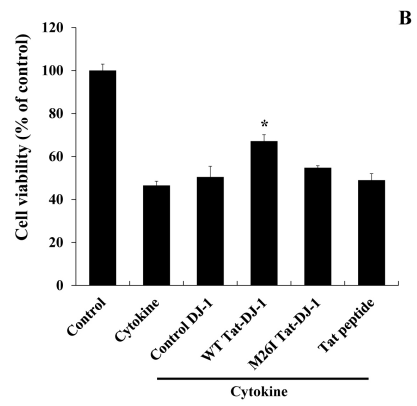

B
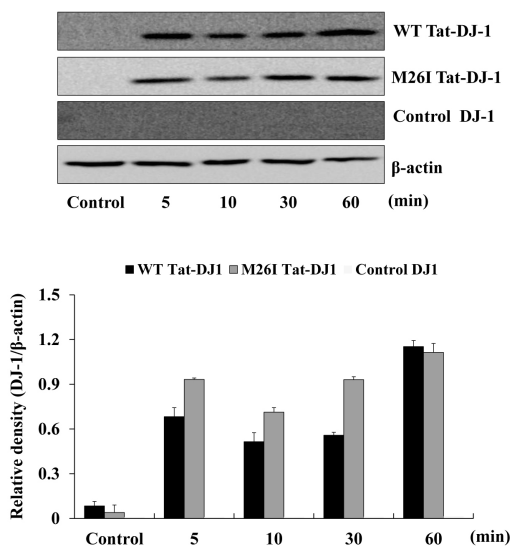

Fig. 2. Tat-DJ-1 proteins transduced into RINm5F cells. Tat-DJ-1 (0.5-3 $\mu \mathrm{M})$ proteins were added to the cell culture media for $1 \mathrm{~h}$ (A), Tat-DJ-1 (3 $\mu \mathrm{M})$ proteins were added to the cell culture media for 5-60 min (B). The stability of Tat-DJ-1 proteins in RINm5F cells. The cells were treated with 3 $\mu \mathrm{M}$ Tat-DJ-1 proteins and incubated for 1-72 $\mathrm{h}$, and analyzed by Western blotting and bands intensity was measured by densitometer (C).

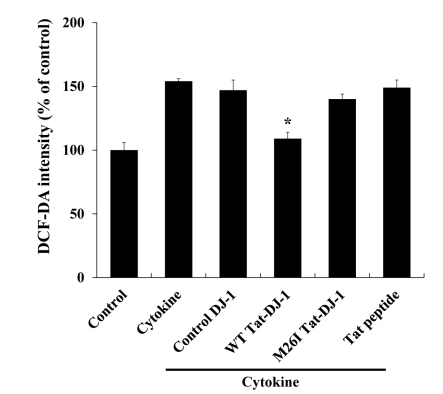

C
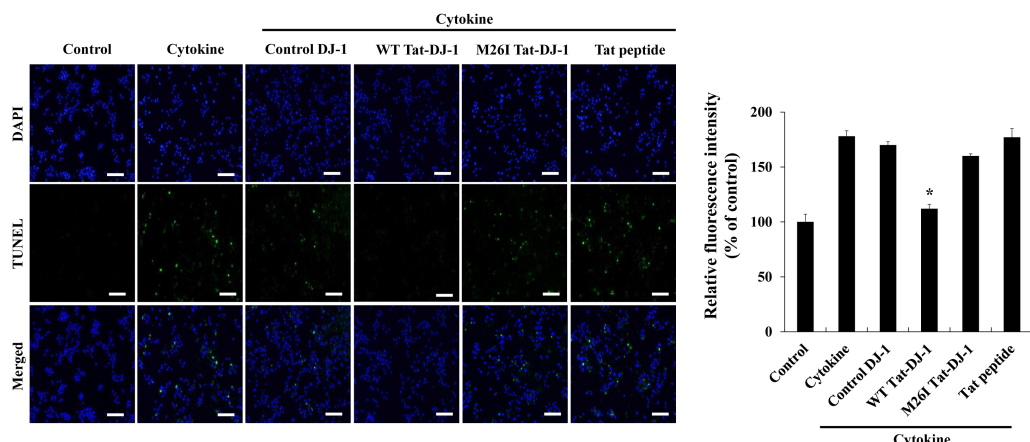

Fig. 3. Effects of Tat-DJ-1 proteins on cytokine-induced cellular cytotoxicity. Tat-DJ-1 proteins $(3 \mu \mathrm{M})$ were pretreat with RINm5F cells for $1 \mathrm{~h}$ and

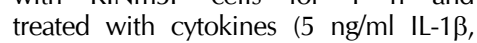
$10 \mathrm{ng} / \mathrm{ml}$ TNF- $\alpha$, and $10 \mathrm{ng} / \mathrm{ml}$ IFN- $\gamma$ ). Then cell viability was determined (A), ROS production (B), and DNA fragmentation (C) as described in Materials and Methods. ${ }^{*} P<0.01$, compared with cytokine-treated cells. 
of caspase- 9 , and subsequently the activation of caspase- 3 that leads to cell death (29-31). In addition, anti-apoptotic protein $\mathrm{BCl}-2$ and pro-apoptotic protein Bax expression are involved with apoptotic cell death (32). Thus, we examined the effect of Tat-DJ-1 protein on cytokine-induced apoptotic signaling in RINm5F cells. Fig. 4 showed how WT Tat-DJ-1 protein significantly inhibited cytokine-induced cytochrome $c$ release and activation of caspase-3, while M26I Tat-DJ-1 and control DJ-1 proteins showed little affect, as compared to WT Tat-DJ-1 protein. Also, we demonstrated that WT Tat-DJ-1 protein markedly increased $\mathrm{Bcl}-2$ expression levels in cytokine exposed cells. In contrast, WT Tat-DJ-1 protein reduced Bax expression levels unlike M26I Tat-DJ-1 and control DJ-1 and showed similar expression levels compared to cytokine only treated control cells. These results indicated that WT Tat-DJ-1 protein has a protective function against cytokine-induced RINm5F cell death via regulation of cell survival signaling pathways. In this regard, WT Tat-DJ-1 protein has a beneficial effect against cytokines.

Taken together, we demonstrated that transduced WT Tat-DJ-1 protein has a beneficial protective effect against cytokine-induced RINm5F cell death, suggesting that WT Tat-DJ-1 protein is a potential therapeutic agent for DM.

\section{MATERIALS AND METHODS}

\section{Materials and cell culture}

Cytokines (IL-1 $\beta$, IFN- $\gamma$ and TNF- $\alpha$ ) were obtained from R\&D system (Minneapolis, MN, USA). Primary, secondary, and $\beta$-actin antibodies were obtained from Cell Signaling Technology (Beverly, MA, USA) and Santa Cruz Biotechnology (Santa Cruz, CA, USA). Mutant M26I DJ-1 cDNA was obtained from Dr. Eun-Hye Joe (Ajou University). Tat peptides were purchased from PEPTRON (Daejeon, Korea). All other agents were of the highest grade available unless otherwise stated.

RINm5F cells, a pancreatic $\beta$-cell line, were purchased from the ATCC (Manassas, VA, USA) and grown in RPMI1640 medium containing $10 \%$ fetal bovine serum (FBS) and antibiotics $(100 \mu \mathrm{g} / \mathrm{ml}$ streptomycin, $100 \mathrm{U} / \mathrm{ml}$ penicillin) at $37^{\circ} \mathrm{C}$ in a humidity chamber with $5 \% \mathrm{CO}_{2}$ and $95 \%$ air.

\section{Construction and purification of Tat-DJ-1 protein}

Tat expression vector was prepared as described previously (33). Briefly, human DJ-1 cDNA were amplified by PCR using the sense primer 5'-CTCGAGGCTTCCAAAAGAGC-3' and the antisense primer, 5'-GGATCCCTAGTCTTTAAGAA-3'. After PCR, the product was cloned in a TA cloning vector and ligated into the Tat expression vector.

The Tat-DJ-1 expression vectors were transformed into $E$. coli BL21 cells and induced with IPTG $(0.5 \mathrm{mM})$ at $37^{\circ} \mathrm{C}$ for 3-4 h. Then, harvested cells were lysed and Tat-DJ-1 proteins
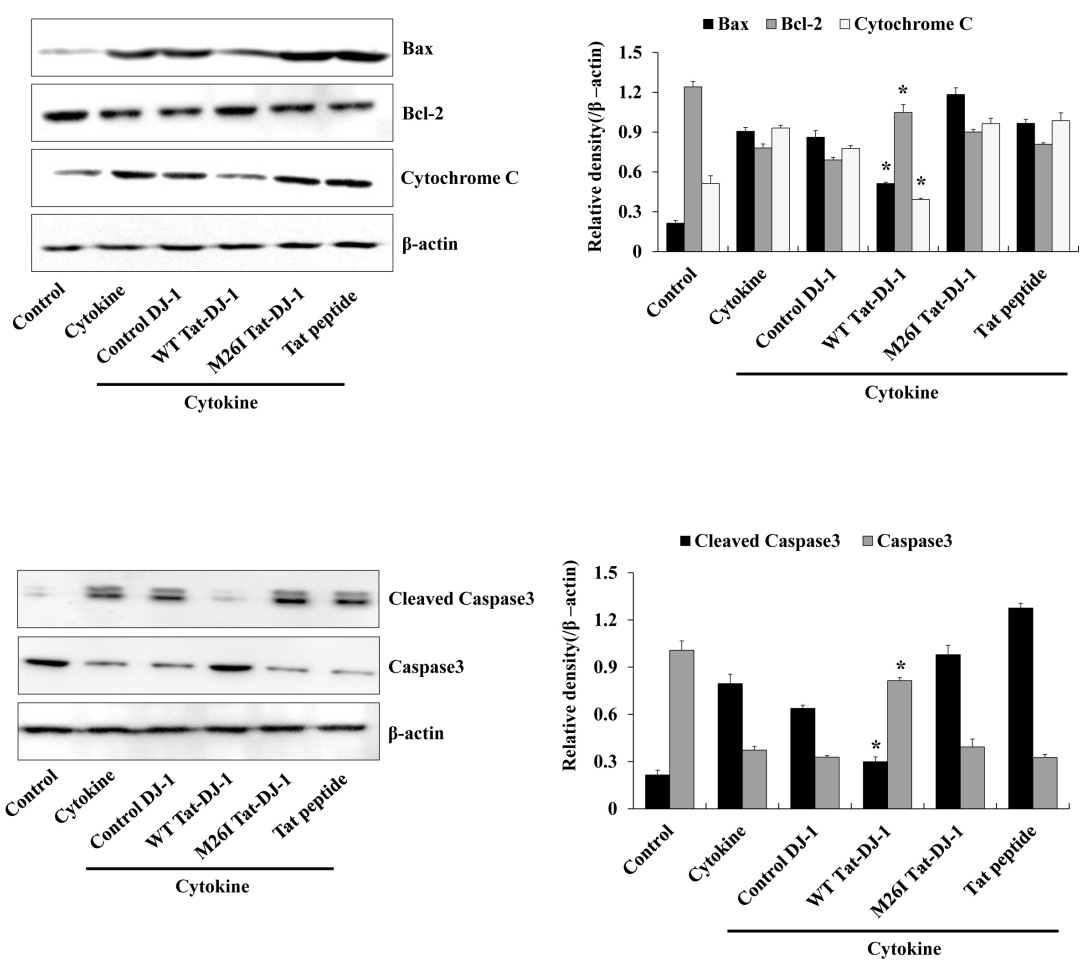

Fig. 4. Effects of Tat-DJ-1 protein against cytokine-induced apoptotic signaling in RINm5F cells. The cells were treated with Tat-DJ- 1 proteins (3 $\mu \mathrm{M})$ for $1 \mathrm{~h}$, and then treated with cytokines $(5 \mathrm{ng} / \mathrm{ml} \quad \mathrm{IL}-1 \beta, 10 \mathrm{ng} / \mathrm{ml}$ TNF- $\alpha$, and $10 \mathrm{ng} / \mathrm{ml}$ IFN- $\gamma$ ), as described in Materials and Methods. The indicated protein expression levels were measured by Western blotting and the band intensity were measured by densitometer. ${ }^{*} P<0.01$, compared with cytokine-treated cells. 
were purified using affinity column chromatograph. Purified protein concentration was determined by the Bradford assay (34).

\section{Confocal microscopy analysis}

To examine the transduction of Tat-DJ-1 proteins into RINm5F cells, we performed double staining using Alexa fluor 488 and DAPI, as described previously (20). After the cells were treated with Tat-DJ-1 proteins for $1 \mathrm{~h}$, the cells were washed, fixed, permeabilized and blocked. Subsequently, the cells were incubated with a His primary antibody and Alexa fluor 488 secondary antibody in the dark. Nuclei were stained for 2 min with $1 \mu \mathrm{g} / \mathrm{ml}$ DAPI (Roche). The cells were observed using a FV-300 confocal microscopy (Olympus, Tokyo, Japan).

\section{Tat-DJ-1 protein transduction into RINm5F cells}

To assess the transduction of Tat-DJ-1 protein, RINm5F cells were treated with Tat-DJ-1 protein $(0.5-3 \mu \mathrm{M})$ for $1 \mathrm{~h}$ or treated with Tat-DJ-1 protein $(3 \mu \mathrm{M})$ for various times (5-60 min). The cells were then treated with trypsin-EDTA and washed with phosphate-buffered saline (PBS) and harvested for the preparation of cell extracts to perform Western blot analysis.

\section{Western blot analysis}

Samples of equal amount of proteins were separated with $12 \%$ SDS-PAGE and transferred to a nitrocellulose membrane. The membrane was blocked with $5 \%$ nonfat dry milk in TBST buffer (25 mM Tris- $\mathrm{HCl}, 140 \mathrm{mM} \mathrm{NaCl}, 0.1 \%$ Tween 20, pH 7.5) for $1 \mathrm{~h}$ and incubated with primary and secondary antibodies at room temperatures. The indicated protein bands were detected using chemiluminescent reagents (Amersham, Franklin Lakes, NJ, USA) (22).

\section{Cell viability assay}

Cell viability was analyzed by colorimetric assay using 3-(4,5-dimethylthiazol-2-yl)-2,5-diphenyltetrazolium bromide (MTT), as described in previous studies (35). Briefly, the cells were pretreated with Tat-DJ-1 protein $(3 \mu \mathrm{M})$ for $1 \mathrm{~h}$ and cytokines (5 ng/ml IL-1 $\beta, 10 \mathrm{ng} / \mathrm{ml} \mathrm{TNF-} \alpha$, and $10 \mathrm{ng} / \mathrm{ml} \mathrm{IFN- \gamma}$ ) were added to the culture medium for $22 \mathrm{~h}$. Cell viability was measured at $570 \mathrm{~nm}$ using an ELISA microplate reader (Labsystems Multiskan MCC/340) and cell viability was defined as the percentage of untreated control cells.

\section{Measurement of ROS levels}

Cytokine-induced intracellular ROS levels were determined using dichlorofluorescein diacetate (DCF-DA) staining, as described previously (22). RINm5F cells were pretreated with Tat-DJ-1 protein $(3 \mu \mathrm{M})$ for $1 \mathrm{~h}$ and treated with cytokines $(5$ $\mathrm{ng} / \mathrm{ml} \mathrm{IL-1} \beta, 10 \mathrm{ng} / \mathrm{ml}$ TNF- $\alpha$, and $10 \mathrm{ng} / \mathrm{ml} \mathrm{IFN}-\gamma$ ) for $15 \mathrm{~min}$. Then, the cells were washed twice with PBS and incubated with DCF-DA $(20 \mu \mathrm{M})$ for $30 \mathrm{~min}$. The fluorescence intensity was measured at $485 \mathrm{~nm}$ excitation and $538 \mathrm{~nm}$ emission using a Fluoroskan ELISA plate reader (Labsystems Oy,
Helsinki, Finland).

\section{TUNEL assay}

RINm5F cells were incubated in the absence or presence of Tat-DJ-1 $(3 \mu \mathrm{M})$ for $1 \mathrm{~h}$, and then treated with cytokines (5 $\mathrm{ng} / \mathrm{ml} \mathrm{IL-1} \beta, 10 \mathrm{ng} / \mathrm{ml} \mathrm{TNF}-\alpha$, and $10 \mathrm{ng} / \mathrm{ml} \mathrm{IFN}-\gamma)$ for $24 \mathrm{~h}$. DNA fragmentation was determined by Terminal deoxynucleotidyl transferase (TdT)-mediated biotinylated dUTP nick end labeling (TUNEL) staining kit (Roche Applied Science) according to the manufacturer's instructions (22). Images were taken using a fluorescence microscope (Nikon eclipse 80i, Japan) and fluorescence intensity was measured using a Fluoroskan ELISA plate reader (Labsystems Oy, Helsinki, Finland) at $485 \mathrm{~nm}$ excitation and $538 \mathrm{~nm}$ emission.

\section{Statistical analysis}

The obtained data were expressed as the means \pm SD from three experiments. Differences among means were analyzed using one-way ANOVA and student's t-test. $\mathrm{P}<0.01$ was significantly different.

\section{ACKNOWLEDGEMENTS}

This work was supported through the National Research Foundation of Korea funded by the Ministry of Education (2014R1A1A4A01008026) and it was also supported by a Priority Research Centers Program grant (NRF-2009-0093812) through the National Research Foundation of Korea funded by the Ministry of Science, ICT \& Future Planning in the Republic Korea, and by Hallym University Research Fund (HRF-G2015-2).

\section{REFERENCES}

1. Eizirik DL, Colli ML and Ortis F (2009) The role of inflammation in insulitis and beta-cell loss in type 1 diabetes Nat Rev Endocrinol 5, 219-226

2. Cnop M, Vidal J, Hull RL et al (2007) Progressive loss of beta-cell function leads to worsening glucose tolerance in first-degree relatives of subjects with type 2 diabetes. Diabetes Care 30, 677-682

3. Shaw JE, Sicree RA and Zimmet PZ (2010) Global estimates of the prevalence of diabetes for 2010 and 2030. Diabetes Res Clin Pr 87, 4-14

4. Agrawal NK, Maiti R, Dash D and Pandey BL (2007) Cilostazol reduces inflammatory burden and oxidative stress in hypertensive type 2 diabetes mellitus patients. Pharmacol Res 56, 118-123

5. Lundh M, Scully SS, Mandrup-Poulsen T and Wagner BK (2013) Small-molecule inhibition of inflammatory beta cell death. Diabetes Obes Metab 15, Suppl 3, 176-184

6. Tang FM, Liu ZZ, Zhao LX, Yang XH, Zhao JJ and Shi J (2013) Effect of glycose control in type 2-diabetes patients on inflammatory factors. Biomed Eng Clin Med 17, $474-476$ 
7. Donath MY and Shoelson SE (2011) Type 2 diabetes as an inflammatory disease. Nat Rev Immunol 11, 98-107

8. Nagakubo D, Taira T, Kitaura $\mathrm{H}$ et al (1997) DJ-1, a novel oncogene which transforms mouse NIH3T3 cells in cooperation with ras. Biochem Biophys Res Commun 231, 509-513

9. Inden M, Taira T, Kitamura $Y$ et al (2006) PARK7 DJ-1 protects against degeneration of nigral dopaminergic neurons in Parkinson's disease rat model. Neurobiol Dis 24, 144-158

10. Kim RH, Smith PD, Aleyashin $\mathrm{H}$ et al (2005) Hypersensitive of DJ-1-deficient mice to 1-methtyl-4-phenyl-1,2, 3,6-tetrahydropyrindine (MPTP) and oxidative stress. Proc Natl Acad Sci U S A 102, 5215-5220

11. Yu HH, Xu Q, Chen HP et al (2013) Stable overexpression of DJ-1 protects $\mathrm{H} 9 \mathrm{c} 2$ cells against oxidative stress under a hypoxia condition. Cell Biochem Funct 31, 643-651

12. Kim W, Kim DW, Jeong HJ et al (2014) Tat-DJ-1 protects neurons from ischemic damage in the ventral horn of rabbit spinal cord via increasing antioxidant levels. Neurochem Res 39, 187-193

13. Bonifati V, Oostra BA and Heutink P (2004) Linking DJ-1 to neurodegeneration offers novel insights for understanding the pathogenesis of Parkinson's disease. J Mol Med 82, 163-174

14. van den Berg A and Dowdy SF (2011) Protein transduction domain delivery of therapeutic macromolecules. Curr Opin Biotechnol 22, 888-893

15. Kubo E, Fatma N, Akagi Y, Beier DR, Singh SP and Singh DP (2008) TAT-mediated PRDX6 protein transduction protects against eye lens epithelial cell death and delays lens opacity. Am J Physiol Cell Physiol 294, C842-C855

16. Kim MJ, Jeong HJ, Kim DW et al (2014) PEP-1-PON1 protect regulates inflammatory response in Raw 264.7 macrophages and ameliorates inflammation in a TPAinduced animal model. PLoS One 9, e86034

17. Zho Z, Li Y, Yuan C, Zhang Y and Qu L (2015) Oral administration of TAT-PTD-Diapause hormone fusion protein interferes with Helicoverpa armigera (Lepidoptera: noctuidae) development. J Insect Sci 15, 123

18. Ramsey JD and Flynn NH (2015) Cell-penetrating peptides transport therapeutics into cells. Pharmcol Therapeut 154, 78-86

19. Hou CL, Huang Q, Wei $Y$ et al (2012) Protein transduction domain-Ha20 fusion protein protects endothelial cells against high glucose-induced injury. Genet Mol Res 11, 1899-1908

20. Kim MJ, Park MY, Kim DW et al (2015) Transduced PEP-1-PON1 proteins regulate microglial activation and dopaminergic neuronal death in a Parkinson's disease model. Biomaterials 64, 45-56

21. Kim YN, Kim DW, Jo HS et al (2015) Tat-CBR1 inhibits inflammatory response through the suppression of NK-kB and MAPKs activation in macrophages and TPA-induced ear edema in mice. Toxicol Applied Pharmacol 286, 124-134

22. Eom SA, Kim DW, Shin MJ et al (2015) Protective effects of PEP-1-Catalase on stress-induced cellular toxicity and MPTP-induced Parkinson's disease. BMB Rep 48, 395-400

23. Yokota T, Sugawara K, Ito K, Takahashi R, Ariga $H$ and Mizusawa H (2003) Down regulation of DJ-1 enhances cell death by oxidative stress, ER stress, and proteasome inhibition. Biochem Biophys Res Commun 312, 13421348

24. Lakshminarasimhan M, Maldonado MT, Zhou W, Fink AL and Wilson MA (2008) Structural impact of three Parkinsonism-associated missense mutations on human DJ-1. Biochem 47, 1381-1392

25. Macedo MG, Anar B, Bronner IF et al (2003) The DJ-1L166P mutant protein associated with early onset Parkinson's disease is unstable and forms higher-order protein complexes. Hum Mol Genet 12, 2807-2816

26. Rabinovitch A and Suarez-Pinzon WL (1998) Cytokines and their roles in pancreatic islet beta-cell destruction and insulin-dependent diabetes mellitus. Biochem Pharmacol 55, 1139-1149

27. Papaccio G, Nicoletti F, Pisanti FA, Galdieri $M$ and Bendtzen K (2002) An imidazoline compound completely counteracts interleukin-1[beta] toxic effects to rat pancreatic islet [beta] cells. Mol Med 8, 536-545

28. Burkart $\mathrm{V}$ and Kolb $\mathrm{H}$ (1993) Protection of islet cells from inflammatory cell death in vitro. Clin Exp Immunol 93, 273-278

29. Riedl SJ and Shi Y (2004) Molecular mechanisms of caspase regulation during apoptosis. Nat Rev Mol Cell Biol 5, 897-907

30. Ghavami S, Hashemi M, Ande SR et al (2009) Apoptosis and cancer: mutations within caspase genes. J Med Genet 46, $497-510$

31. Fulda S and Debatin KM (2006) Extrinsic versus intrinsic apoptosis pathways in anticancer chemotherapy. Oncogene 25, 4798-4811

32. Reed JC (2006) Proapoptotic multidomain Bcl-2/Bax-family protein: Mechanisms, physiological roles, and therapeutic opportunities. Cell Death Differ 13, 1378-1386

33. Kwon HY, Eum WS, Jang HW et al (2000) Transduction of $\mathrm{Cu}, \mathrm{Zn}$-superoxide dismutase mediated by an HIV-1 Tat protein basic domain into mammalian cells. FEBS Lett 485, 163-167

34. Bradford MA (1976) Rapid and sensitive method for the quantitation of microgram quantities utilizing the principle of protein-dye binding. Anal Biochem 72, 248-254

35. Seo WY, Youn GS, Choi SY and Park J (2015) Butein, a tetrahydroxychalcone, suppresses pro-inflammatory responses in HaCaT keratinocytes. BMB Rep 48, 495-500 